\title{
Will Parks
}

\section{Achieving Results for Pacific Island Children: UNICEF's Analysis}

of and Response to Pacific Millennium Development Goal Progress

in partnership with many agencies across the region to assist countries to advance their child-related MDGs. Finally, I consider some of the challenges to sustaining MDG progress for children in Pacific Island countries, especially the current global economic crisis.

Progress towards Millennium Development Goals in the Pacific At the Millennium Summit in 2000, leaders of 189 United Nations member states, including all 14 Pacific Island country leaders, endorsed the Millennium Declaration and adopted the global agenda designated as the Millennium Development Introduction ${ }^{1}$

The Pacific Island countries are home to some 2 million people, of whom just over 900,000 are under 18 years of age (UNICEF, 2007). ${ }^{2}$ In this article I briefly review the progress Pacific Island countries have made towards their Millennium Development Goals (MDGs), with a particular focus on MDG4 (reduce child mortality) and MDG5 (improve maternal health). I then highlight some of the support being provided by the United Nations Children’s Fund (UNICEF)

Based in Fiji, Dr Will Parks is UNICEF Pacific's Chief of Policy, Advocacy, Planning and Evaluation covering child-focused programmes in 14 Pacific Island countries. Prior to joining UNICEF he worked globally in over 35 countries with the World Health Organization, AusAID and DFID on various social development issues.
Goals or MDGs (United Nations, 2000). The MDGs comprise a set of eight interrelated, priority development goals with corresponding indicators and time-bound targets, to be reached by 2015, all aimed at eradicating poverty in all its forms. MDG progress in the Pacific region has been described as 'mixed', with no country in the region likely to achieve all their MDGs if the status quo is maintained (UNESCAP, UNDP and ADB, 2008).

\section{MDG1: Eradicate extreme poverty and hunger}

Poverty in the Pacific Island context has not generally meant hunger or destitution, but a continuous struggle to meet essential living expenses, particularly those that require cash payments. Measuring progress towards the achievement of MDGl for poverty reduction in the Pacific has been problematic, with few historic poverty estimates and no upto-date purchasing power parity (PPP) indices. However, the latest available poverty estimates, based on national basic needs poverty lines derived from household income and expenditure surveys (HIES), suggest that one in four households and almost one in three of the population are below their respective national poverty lines (Abbott, 2008). With regard to nutritional status, the Pacific is facing a double burden, with both protein-energy and micronutrient malnutrition coexisting with obesity. Recent data from four demographic health surveys (DHS) - in Nauru, Republic 
of Marshall Islands, Solomon Islands and Tuvalu - and a multiple indicator cluster survey (MICS) in Vanuatu suggest that between $1.6 \%$ (Tuvalu) and 16\% (Vanuatu) of under-five children are underweight, with an average across these five surveys of 9.4\% (Prasad, 2009; Government of Vanuatu and UNICEF, 2008).

\section{MDG2: Achieve universal primary education}

So far, none of the 14 Pacific Island countries has achieved full enrolment at both primary and secondary level. Only the Cook Islands, Federated States of Micronesia, Niue, Tokelau and Tuvalu claim 100\% primary education enrolment ratios (Prasad, 2009). Other national averages for MDG2 indicators conceal sub-national disparities. The 2008 MICS survey in Vanuatu, for example, reveals that the primary school net attendance ratio - defined as the percentage of children of primary school age (6-11 years) attending primary school or secondary school - is $80 \%$ overall but varies from $93 \%$ in Malampa province to $70 \%$ in Tafea province (Government of Vanuatu and UNICEF, 2008).

\section{MDG3: Promote gender equality and empower women}

Most Pacific Island countries have achieved an equal ratio of girls to boys (gender parity) in primary school level or close to

Table 1: Most recent under-five mortality rates for 14 Pacific Island countries and percentage reductions since 1990

\begin{tabular}{|c|c|c|c|}
\hline \multirow[b]{2}{*}{ Country } & \multicolumn{2}{|c|}{$\begin{array}{l}\text { Most recent under-five mortality } \\
\text { rate }\end{array}$} & \multirow{2}{*}{$\begin{array}{l}\text { Reduction since } \\
1990 \text { - target is } \\
67 \% \text { reduction } \\
\text { by } 2015 \\
\text { (UNICEF, 2009a) }\end{array}$} \\
\hline & $\begin{array}{l}\text { SPC and UNICEF } \\
\text { Pacific sources }\end{array}$ & $\begin{array}{l}\text { CME Info } \\
(2007)\end{array}$ & \\
\hline Cook Islands & $\begin{array}{l}26.1 \text { (Central health } \\
\text { admin 2001) }\end{array}$ & 18 & $44 \%$ \\
\hline FSM & $\begin{array}{l}47 \text { (Central health } \\
\text { admin 2001) }\end{array}$ & 40 & $31 \%$ \\
\hline Fiji Islands & $\begin{array}{l}22.4 \text { (Central health } \\
\text { admin 2002) }\end{array}$ & 18 & $18 \%$ \\
\hline Kiribati & $\begin{array}{l}69 \text { (Central health } \\
\text { admin 2005) }\end{array}$ & 63 & $28 \%$ \\
\hline Nauru & 38 (DHS 2007) & 30 & $\mathrm{n} / \mathrm{a}$ \\
\hline Niue & $\begin{array}{l}19 \text { (Central health } \\
\text { admin 2006) }\end{array}$ & $\mathrm{n} / \mathrm{a}$ & $\mathrm{n} / \mathrm{a}$ \\
\hline Palau & $\begin{array}{l}38.9 \text { (Central health } \\
\text { admin 2005) }\end{array}$ & 10 & $52 \%$ \\
\hline RMI & 46 (DHS 2007) & 54 & $41 \%$ \\
\hline Samoa & $\begin{array}{l}24.7 \text { (Central health } \\
\text { admin 2006) }\end{array}$ & 27 & $46 \%$ \\
\hline Solomon Is & 37 (DHS 2007) & 71 & $42 \%$ \\
\hline Tokelau & $\mathrm{n} / \mathrm{a}$ & $\mathrm{n} / \mathrm{a}$ & $\mathrm{n} / \mathrm{a}$ \\
\hline Tonga & $\begin{array}{l}21.9 \text { (Central health } \\
\text { admin 2006) }\end{array}$ & 23 & $28 \%$ \\
\hline Tuvalu & 36 (DHS 2007) & 37 & $30 \%$ \\
\hline Vanuatu & 30 (MICS 2008) & 34 & $45 \%$ \\
\hline
\end{tabular}

Sources: Haberkorn, 2009; Child Mortality Estimates INFO (http:// www.childmortality.org); Government of Vanuatu and UNICEF, 2008; and UNICEF, 2009a gender parity at the primary school level. Cook Islands at 0.88, Republic of Marshall Islands at 0.91, Palau at 0.92, Samoa at 0.93, Solomon Islands at 0.89, Tonga at 0.90, and Tuvalu at 0.88 are more below gender parity than others (Prasad, 2009). Niue at 0.87 and Solomon Islands at 0.77 are noticeably below gender parity at the secondary school level (Prasad, 2009). Among the greatest gender challenges in the Pacific are: the low percentage of women in wage employment in the non-agricultural sector ${ }^{3}$; only around $5 \%$ of seats are held by women in national parliament (ADB, 2008; Prasad, 2009); and the pervasive high prevalence of gender-based violence (see, e.g., EPPSO, SPG and Macro International Inc., 2007).

\section{MDG4: Reduce child mortality}

Despite steady reductions in child mortality, an estimated aggregate of around 2,500 children under five years of age still die every year in the Pacific region. ${ }^{4}$ Four out of five of these children are under one year of age. Tables 1 and 2 present the most recent under-five and infant mortality rates for the 14 Pacific Island countries, using sources collated by the Secretariat of the Pacific Community (SPG) and UNICEF Pacific, together with data from UNICEF's child mortality estimates database (CME Info). ${ }^{5}$ Table 1 also shows the percentage reduction in respective under-five mortality

Table 2: Most recent infant mortality rates for 14 Pacific Island countries and percentage of under-five mortality represented by infant mortality

\begin{tabular}{|c|c|c|c|}
\hline \multirow[b]{2}{*}{ Country } & \multicolumn{2}{|c|}{ Most recent infant mortality rate } & \multirow{2}{*}{$\begin{array}{l}\text { Percentage } \\
\text { of under-five } \\
\text { mortality } \\
\text { represented by } \\
\text { infant mortality }\end{array}$} \\
\hline & $\begin{array}{l}\text { SPC and UNICEF } \\
\text { Pacific sources }\end{array}$ & $\begin{array}{l}\text { CME Info } \\
(2007)\end{array}$ & \\
\hline Cook Islands & $\begin{array}{l}11.9 \text { (Census, health } \\
\text { admin 2001) }\end{array}$ & 15.8 & $88 \%$ \\
\hline FSM & $\begin{array}{l}40 \text { (Census, health } \\
\text { admin 2001) }\end{array}$ & 32.9 & $82 \%$ \\
\hline Fiji Islands & $\begin{array}{l}17.8 \text { (Health admin } \\
2002 \text { ) }\end{array}$ & 15.6 & $87 \%$ \\
\hline Kiribati & $\begin{array}{l}52 \text { (Census, health } \\
\text { admin 2005) }\end{array}$ & 46.4 & $74 \%$ \\
\hline Nauru & 38 (DHS 2007) & 25.0 & $83 \%$ \\
\hline Niue & $\begin{array}{l}7.8 \text { (Census, health } \\
\text { admin 2006) }\end{array}$ & $\mathrm{n} / \mathrm{a}$ & - \\
\hline Palau & $\begin{array}{l}20 \text { (Census, health } \\
\text { admin 2005) }\end{array}$ & 9.4 & $94 \%$ \\
\hline RMI & 33 (DHS 2007) & 49.4 & $92 \%$ \\
\hline Samoa & $\begin{array}{l}20.4 \text { (Census, health } \\
\text { admin 2006) }\end{array}$ & 22.5 & $83 \%$ \\
\hline Solomon is & 24 (DHS 2007) & 53.4 & $75 \%$ \\
\hline Tokelau & $\mathrm{n} / \mathrm{a}$ & $\mathrm{n} / \mathrm{a}$ & - \\
\hline Tonga & $\begin{array}{l}19 \text { (Census, health } \\
\text { admin 2006) }\end{array}$ & 19.2 & $83 \%$ \\
\hline Tuvalu & 31 (DHS 2007) & 30.2 & $82 \%$ \\
\hline Vanuatu & 25 (MICS 2008) & 28.1 & $83 \%$ \\
\hline
\end{tabular}

Sources: Haberkorn, 2009; Child Mortality Estimates INFO (http:// www.childmortality.org); Government of Vanuatu and UNICEF, 2008; and UNICEF, 2009a 
rates since 1990. The $2015 \mathrm{MDG}$ target reduction is $67 \%$ of the 1990 figure.

At least three points are worth noting: first, the variations in data between SPG sources and CME Info, especially for Palau and Solomon Islands. The difference in the figures for Solomon Islands is straightforward - the 2007 demographic health survey data has not been formally released by the government and thus has not been officially recorded within UNICEF's CME Info database. The difference in the figures for Palau is likely to reflect a similar delay in updating the SPC database. Both the government of Palau situation analysis report on children and women and the government of Palau MDG report register an under-five mortality rate of 7.2 using Ministry of Health data (Government of Palau, 2008a; Government of Palau, 2008b). These disparities together with the other minor differences, however, strongly indicate the need for governments and development partners to ensure better integrity between national, regional and international databases.

The second thing worth noting in Table 1 is the countries that have made significant progress towards the $67 \%$ reduction target by 2015, notably the Cook Islands, Palau (if data in CME Info is used), Republic of Marshall Islands, Samoa, Solomon Islands and Vanuatu. Fiji Islands has made little progress towards reducing its 1990 under-five mortality rate - so far achieving only $18 \%$ of its $67 \%$ target. It should be noted that Fiji's 1990 under-five mortality rate was already much lower than that in most Pacific Island countries (estimated at 22). Further analysis of why certain countries are making strong progress to reduce child mortality whereas as

Figure 1: Trends in under-five and infant mortality rates between 1990 and 2015 for Tonga

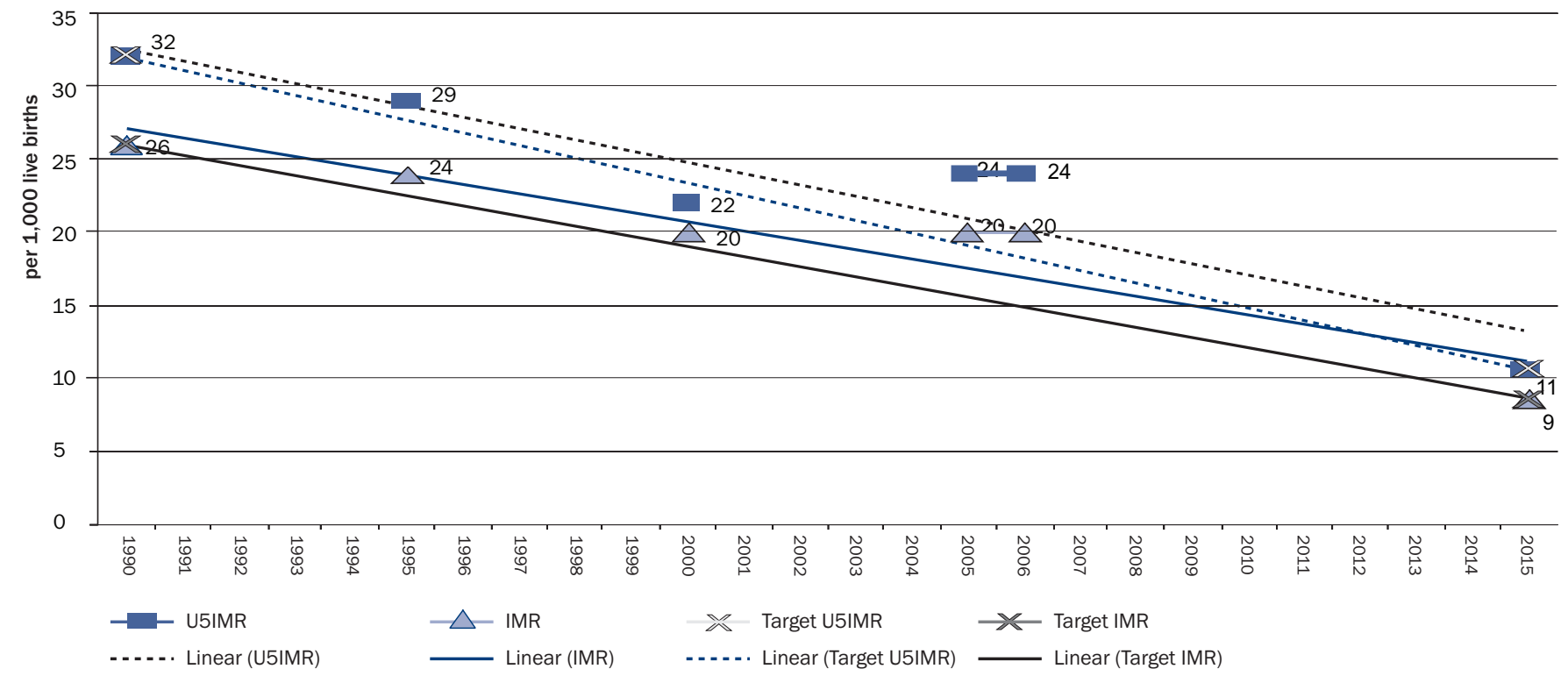

Figure 2: Trends in under-five and infant mortality rates between 1990 and 2015 for Kiribati

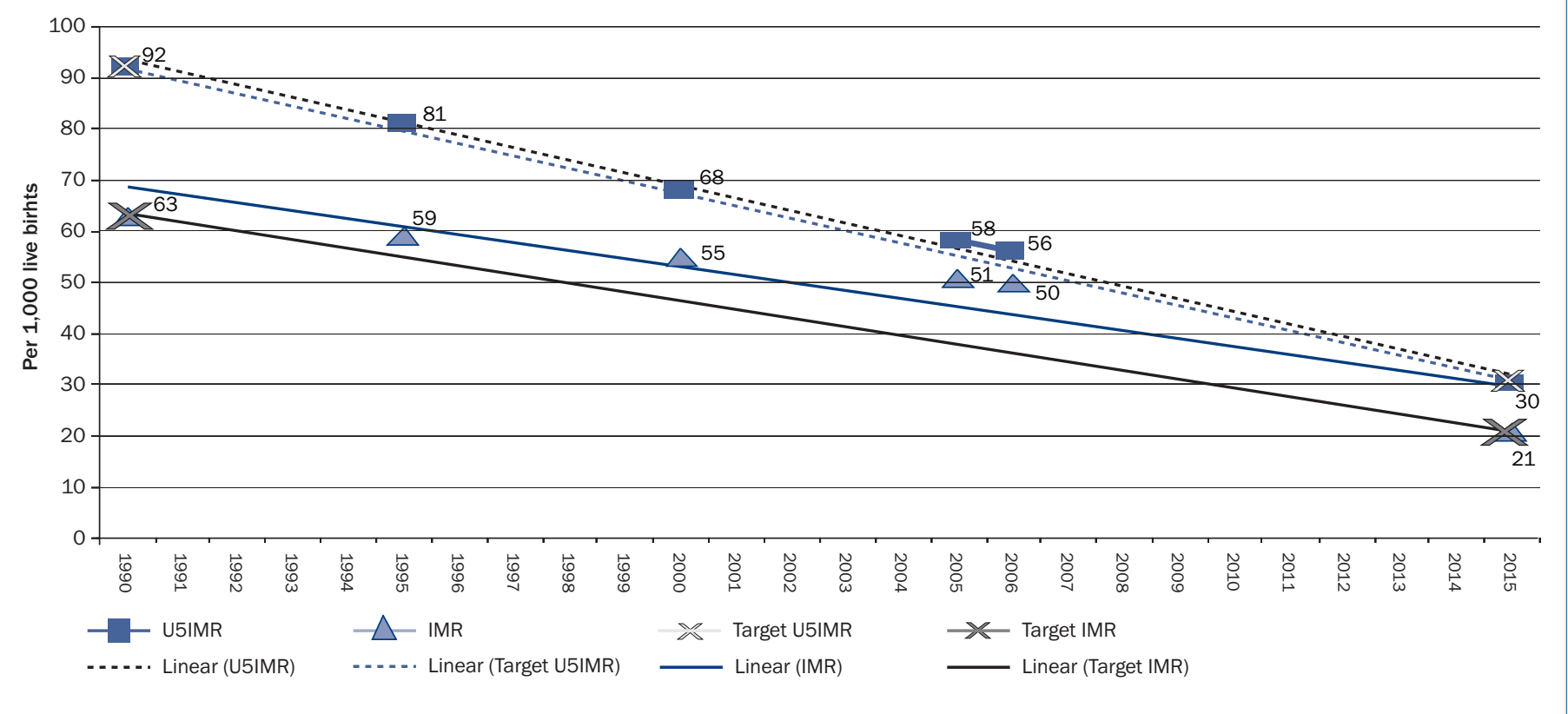


others are not would be insightful. Sub-national comparative analysis would also be instructive.

The third noticeable feature of these data (Table 2) is the high proportion of national under-five mortality rates represented by infant mortality - ranging from $74 \%$ (Kiribati) to $94 \%$ (Palau). As under-five mortality rates drop, the majority of deaths occur within the first year of life, particularly the earliest months and even days of life. Unless health policies, programmes and investments refocus on aggressively targeting the causes of infant mortality (including maternal health), further progress in reducing overall child mortality can stagnate. This would appear to be the case for Fiji.

The need to carefully analyse data and restrategise maternal and child health programmes accordingly is again illustrated by Figures 1 and 2 - showing trends in under-five and infant mortality rates towards 2015 targets for Tonga and Kiribati respectively. Both figures suggest that based on current progress, as 2015 approaches so an increasing proportion of overall deaths are those occurring among infants. Figure 1 suggests that Tonga's under-five and infant mortality rates may be starting to stagnate. Figure 2 suggests that Kiribati's reduction in under-five mortality is more or less on track but its infant mortality rate appears to be veering off-track.

Critical actions to improve progress towards MDG4 across most Pacific Island countries include intensive support for immunisation, childhood nutrition, social mobiliation, strengthened neonatal and child health services, hygiene promotion and the provision of quality safe water and safe sanitation (see MDG7 below).

\section{Table 3: Maternal mortality ratios for 14 Pacific Island}

\section{countries}

\begin{tabular}{|c|c|c|c|c|}
\hline Country & SPC, 2004 & $\begin{array}{l}\text { ADB, } 2008 \\
\text { and other } \\
\text { sources }\end{array}$ & $\begin{array}{l}\text { UNICEF, } \\
2008 \\
\text { (Reported } \\
\text { 2000-2006) }\end{array}$ & $\begin{array}{l}\text { UNICEF, } \\
2008 \\
\text { (Adjusted } \\
2005 \text { ) }\end{array}$ \\
\hline Cook Islands & $\mathrm{n} / \mathrm{a}$ & $\mathrm{n} / \mathrm{a}$ & 6 & $\mathrm{n} / \mathrm{a}$ \\
\hline FSM & 83 (1992) & $n / a$ & 270 & $\mathrm{n} / \mathrm{a}$ \\
\hline Fiji Islands & 41.1 (1988) & $75(2000)$ & 38 & 210 \\
\hline Kiribati & $10_{(1990)}$ & $56(2000)$ & 56 & $\mathrm{n} / \mathrm{a}$ \\
\hline Nauru & $n / a$ & $\mathrm{n} / \mathrm{a}$ & $\mathrm{n} / \mathrm{a}$ & $\mathrm{n} / \mathrm{a}$ \\
\hline Niue & $\mathrm{n} / \mathrm{a}$ & $\mathrm{n} / \mathrm{a}$ & $\mathrm{n} / \mathrm{a}$ & $\mathrm{n} / \mathrm{a}$ \\
\hline Palau & $\mathrm{n} / \mathrm{a}$ & $\mathrm{O}_{(2000)}$ & 0 & $\mathrm{n} / \mathrm{a}$ \\
\hline RMI & $\mathrm{O}_{(1991)}$ & 74 (2002) & 74 & $\mathrm{n} / \mathrm{a}$ \\
\hline Samoa & 140 (1991) & 29 (2001) & 29 & $\mathrm{n} / \mathrm{a}$ \\
\hline Solomon Is & 550 (1992) & 130 (2000) & 140 & 220 \\
\hline Tokelau & $\mathrm{n} / \mathrm{a}$ & $n / a$ & $\mathrm{n} / \mathrm{a}$ & $\mathrm{n} / \mathrm{a}$ \\
\hline Tonga & 39 (1990) & 78 (2000) & 78 & $\mathrm{n} / \mathrm{a}$ \\
\hline Tuvalu & $\mathrm{n} / \mathrm{a}$ & $\mathrm{n} / \mathrm{a}$ & $\mathrm{n} / \mathrm{a}$ & $\mathrm{n} / \mathrm{a}$ \\
\hline Vanuatu & 89.1 (1995) & 98 (1998) & 68 & $\mathrm{n} / \mathrm{a}$ \\
\hline
\end{tabular}

Sources: SPC, 2004; ADB, 2008; Government of Palau, 2008b;

UNICEF, 2008

\section{MDG5: Improve maternal health}

There are questions over the relevancy of using the maternal mortality ratio (MMR) for small populations such as those found in the Pacific. ${ }^{6}$ Nevertheless, as a crude measure of progress, the regional 1990 MMR (based on countries for which data are available) was around 119 (Table 3). This figure seems to drop to 67.5 by 2000 but rises again to 113 by around 2005. The 2015 MDG target is to reduce 1990 MMRs by $75 \%$ - in other words, the regional MMR must drop from 119 to 30 by 2015. While there appear to be some success stories (e.g. Palau, Samoa, Solomon Islands, Vanuatu), this blunt measure suggests that the Pacific as a region has achieved a mere $6 \%$ reduction in MMRs over 14 years and must achieve a further $69 \%$ reduction in just 6 years.

MDG5 remains a serious concern across the Pacific. Leading causes of maternal deaths include post-partum haemorrhage, preclampsia, obstructed labour, puerperal sepsis, complications of unsafe abortion, anaemia and malaria (where prevalent) (SPC, 2004). Despite 80\% of births in the region reported to being attended by skilled health personnel (Table 4), universal access to high quality obstetric care at birth must be accelerated if MDG5 targets for maternal mortality are to be achieved.

Pacific Island countries show a mixed picture for other MDG5 indicators (Table 4). Available time series data suggest that contraceptive prevalence rates have risen in Fiji Islands, Republic of Marshall Islands and Samoa but have

\section{Table 4: Selected indicators of MDG5 for 14 Pacific Island} countries

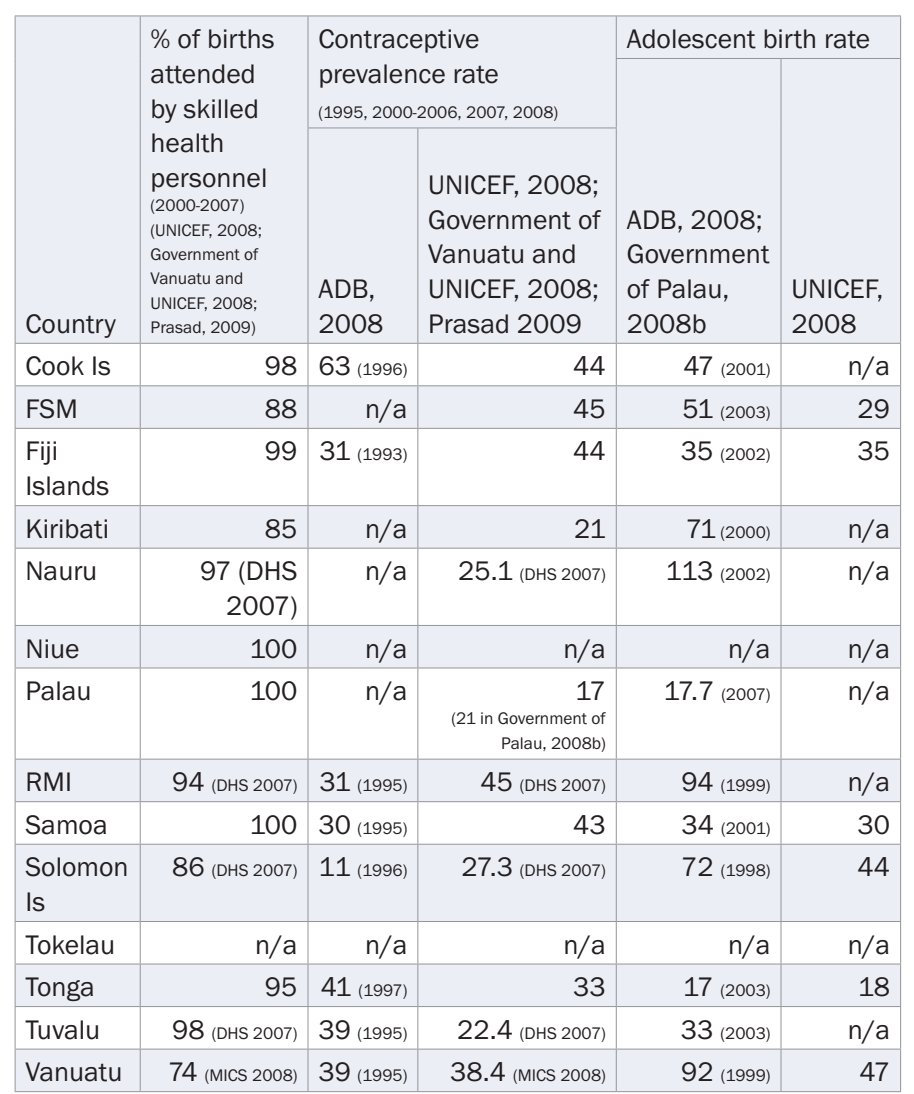

Sources: ADB, 2008; UNICEF, 2008; Government of Palau, 2008b; Government of Vanuatu and UNICEF, 2008; and Prasad, 2009 


\section{UNICEF Pacific's 2008-2012 goal is to support the governments of 14 Pacific Island countries in progressively realising child rights in accordance with national development strategies, the United Nations Development Assistance Framework, Millennium Development Goals, the Millennium Declaration and A World Fit for Children goals.}

decreased in the Cook Islands, Tonga and Tuvalu, with Vanuatu showing little change since $1995 .^{7}$ Federated States of Micronesia, Samoa, Solomon Islands and Vanuatu appear to have made progress in reducing their respective adolescent birth rates but data, for Fiji and Tonga suggest little or no progress. ${ }^{8}$ It should be noted that almost no Pacific Island data are available for antenatal care coverage (percentage of live births) and that no data are available for percentage of unmet need for family planning. ${ }^{9}$

\section{MDG6: Combat HIV and AIDS, malaria and other diseases}

Cumulative HIV case numbers recorded across the Pacific suggest that while HIV transmission within the general population remains low at this point, HIV prevalence in specific groups, such as sex workers, military personnel and maritime workers, is increasing. Based on World Health Organization estimates, Tuvalu has almost reached the point at which HIV prevalence will be generalised (UNICEF, 2007). Several factors that can drive an HIV epidemic are already present in the Pacific: high prevalence of sexually transmitted infections (STIs); limited knowledge of how HIV is transmitted; frequent unsafe sex (particularly among the young); and a high proportion of people have multiple and casual partners (WHO, SPG, UNSW and Global Fund, 2006). The recent MICS in Vanuatu revealed that only 16\% of women aged 1549 years in the survey had comprehensive correct knowledge of HIV (Government of Vanuatu and UNICEF, 2008). ${ }^{10}$

Solomon Islands and Vanuatu both have endemic malaria. DHS data for Solomon Islands reveal that $77 \%$ of under-five children are treated with appropriate anti-malarial drugs, but only $40 \%$ are sleeping under an insecticide-treated bed-net (Prasad, 2009). In Vanuatu, only 36\% of under-five children are treated with appropriate anti-malarial drugs while $56 \%$ are sleeping under an insecticide-treated bed-net (Government of Vanuatu, 2008).

\section{MDG7: Ensure environmental sustainability}

There has been no regional gain since 1990 in the percentage of Pacific Island populations with access to improved water supplies - the regional mean in 1990 was $85 \%$ and it was $85 \%$ in 2006 (ADB, 2008). Some countries have made gains since 1990 (e.g. Federated States of Micronesia, Kiribati, Nauru, Republic of Marshall Islands and Tuvalu), and Tonga has maintained its $100 \%$ access, but others have made no gain (e.g., Cook Islands, Fiji Islands, Solomon Islands) or even regressed (e.g. Samoa and Vanuatu). Sub-national data reveal that access to improved water sources in rural areas remains below $80 \%$. Fiji Islands, Kiribati, Solomon Islands and Vanuatu fall well below this figure (ADB, 2008).

The percentage of Pacific Island populations using improved sanitation has increased slightly - from a regional mean of $70 \%$ in 1990 to $74 \%$ in 2006 (ADB, 2008). Again, some countries have made minor improvements (e.g. Cook Islands, Nauru, Palau, Republic of Marshall Islands and Tuvalu), while others show no gain or reductions. Sub-national data reveal that use of improved sanitation in rural areas remains below 70\%. Federated States of Micronesia, Fiji Islands, Kiribati, Republic of Marshall Islands, Solomon Islands and Vanuatu fall well below this figure (ADB, 2008).

National and regional partners now appear to be investing greater effort towards MDG7, especially in the areas of safe water and sanitation, but it is too early to detect significant changes in key indicators.

\section{MDG8: Develop a global partnership for development}

According to national MDG reports, Palau and Solomon Islands are likely to, while Cook Islands and Tuvalu will probably, achieve MDG8. All other Pacific Island countries have the potential to achieve MDG8 (Prasad, 2009). Aid flow per capita in the Pacific is very large in comparison with other parts of the world but donor coordination and targeting of aid needs to be improved, especially in smaller Pacific Island countries which rely on significant aid flow to maintain current living standards.

\section{Millennium Declaration: Protect the vulnerable}

A major issue for creating a protective environment for children (United Nations, 2000) is how to win widespread community commitment to the rights to protection specified in the United Nations Convention on the Rights of the Child. Stronger commitment is needed in the home, in the wider community and in relation to juvenile justice. While evidence of severe forms of child labour is scarce, estimates by the International Labour Organization suggest that with growing poverty, child workers already make up an estimated 14\% in Solomon Islands (ILO, 2009). Legislation, law enforcement and social services to prevent and cope with the rising incidence of child abuse and domestic violence require strengthening throughout the Pacific (UNICEF, UNESCAP, ECPAT International and RRRT, 2008).

\section{The work of UNICEF in the Pacific}

UNICEF has worked with Pacific Island countries for over 50 years. UNICEF Pacific's 2008-2012 goal is to support the 
governments of 14 Pacific Island countries in progressively realising child rights in accordance with national development strategies, the United Nations Development Assistance Framework, Millennium Development Goals, the Millennium Declaration and A World Fit for Children goals. UNICEF Pacificís strategic vision involves bringing the child dimension to Pacific regional policy debates, emphasising child rights within Pacific regional strategies, and assuring the realisation of key results at scale for children, with a special focus on three priority countries - Kiribati, Solomon Islands and Vanuatu. Robust evaluation will allow the demonstration of impact in these three countries to be channeled into regional Pacific policy and strategy formulation. Regional programming is pursued through cooperation with institutions such as the Secretariat of the Pacific Community, the Asian Development Bank and the United Nations family. UNICEF Pacificís work is currently divided into five core programmes of cooperation: health and sanitation; education; HIV and AIDS; child protection; and policy, advocacy, planning and evaluation. Supporting national emergency preparedness and response is also a major feature of UNICEFís work in the Pacific but not discussed here.

\section{Health and sanitation programme}

In partnership with a large number of health development agencies, this programme aims to: increase childhood immunisation coverage (all vaccines) from a regional mean of $80 \%$ to $90 \%$ by 2012 in all 14 countries, with a special focus on low-performing districts; ensure that implementation of evidence-based maternal and child health plans and programmes is intensified in at least the three priority countries; and support the development and implementation of community-based hygiene improvement and water safety plans that lead to a reduction in childhood diarrhoea and other water-related diseases.

\section{Education programme}

In at least the three priority countries, this programme aims to increase by $10 \%$ the number of children completing the transition to a seventh year of the formal education cycle or its non-formal equivalent by 2012. Non-formal education mechanisms that allow children to complete basic education are also being explored. At a regional level, UNICEF is supporting education sectoral programming and policy development which draw upon a rights-based approach to ensure equitable provision of quality education for all children and young people.

Carefully evaluated child-friendly school initiatives are used as the key policy advocacy tool with ministries of education and key partners to foster a holistic, whole-of-school approach to quality education.

\section{HIV and AIDS programme}

Working with numerous partners, this programme aims to reduce the vulnerability to and impact of HIV and AIDS among the most at-risk populations in at least Fiji, Tuvalu and the three priority countries, through strengthened integration of maternal and child health services and community-based initiatives. Governments are being supported to ensure that all women have access to STI treatment and HIV voluntary and confidential counselling and testing (VCCT), and that all children and women who are HIV positive receive antiretrovirals. The programme advocates for a prevention of mother to child transmission (PMTCT) approach integrated with maternal and child health. Risks and vulnerabilities are being mapped through situation analyses, and support is being provided for monitoring and evaluation systems to determine if these risks and vulnerabilities are being reduced.

\section{Child protection programme}

In at least Fiji, Samoa and the three priority countries, this programme works with a range of partners to: ensure that children are increasingly protected by legislation and are better served by justice systems that protect them as victims, offenders and witnesses; ensure that children are better served by well-informed and coordinated child protection social services that provide greater protection against and response to violence, abuse and exploitation; and support families and communities in establishing home and community environments for children that are free from violence, abuse and exploitation.

\section{Policy, advocacy, planning and evaluation programme}

This programme aims to support the development of social and economic policies that are evidence-based and progressively address the rights of children, youth and women through inclusive mechanisms, and to ensure that quality disaggregated social data on children, young people and women are available and integrated into planning, monitoring and evaluation systems in at least the three priority countries. The programme joins other UN agencies and regional organisations in the provision of technical support to national planning and statistical units and relevant sub-national administrative bodies.

\section{Challenges to sustaining MDG progress for children in Pacific Island countries}

There are many challenges facing Pacific Island countries in their pursuit of national development goals and MDGs,

\section{There are many challenges facing Pacific Island countries in their pursuit of national development goals and MDGs, including geographic isolation, frequent natural disasters, climate change, limited domestic markets, inadequate infrastructure and capacity constraints.}


including geographic isolation, frequent natural disasters, climate change, limited domestic markets, inadequate infrastructure and capacity constraints. In this final section I consider just two challenges - the place of MDGs within national development frameworks and the current global economic crisis.

\section{MDG focus in national planning, policy and budgeting}

Many countries already have or are in the process of redeveloping national development plans. Many of these plans show alignment to MDGs, but more work needs to be done (UNESCAP, ADB and UNDP, 2008). Firstly, while many governments understand that it is impossible to achieve their MDGs through economic growth alone, many national policies remain growth-oriented, with inadequate focus on areas that will help achieve MDGs. Secondly, despite national plans, many countries do not have clear national and sub-national programmatic roadmaps for MDG achievement, and there is very little costing for and specific budget investment in MDGs. Lastly, there is a need to better align national development plans and policies to the Convention on the Rights of the Child to improve the national focus on results for children.

\section{The global economic crisis}

The current global economic crisis presents one of the most serious challenges to the achievement of MDGs in the Pacific, and I conclude with a rapid synopsis of some of the impacts that the crisis may have on children across the region.

The Asian Development Bank has predicted that of the Pacific Island countries considered in this article, only Vanuatu may continue to sustain positive economic growth (ADB, 2009). Even if the global economy picks up in the second half of 2010, lags mean that economic conditions will be tough in the Pacific in 2010 and it may take until 2011 for the Pacific economies to fully recover. The risks of a long and deep recession or even a depression, however, cannot be excluded.

As noted earlier, there are substantial levels of poverty and hardship in the Pacific. The central lesson learned from every previous economic crisis is that the poorest people in developing countries suffer the most and that not enough is done to help them (Gottschalk, 2004). The impact of the current crisis will depend on a variety of factors and will vary between different countries and regions. Nevertheless, children and women in many Pacific Island countries are likely to be amongst those most severely affected, and those already most vulnerable will face the greatest impacts.

Globally, 9.2 million children still die before their fifth birthday every year (UNICEF, 2009b). If the current economic crisis continues unaddressed, between 200,000 and 400,000 extra deaths will occur annually, driven by increasing malnutrition. By 2015 this would equate to an additional 2.8 million child deaths (IMF, 2009). Global estimates may not translate directly to the Pacific, but if we apply the same predictions, unless reversed the economic crisis could result in an increase of between 50 and 100 Pacific Island child deaths annually - almost one more death every three days than currently occurs. Each child death and each additional death represent an enormous loss and a step backwards for the Pacific. Malnutrition, including micronutrient deficiencies, is already common across the Pacific and changes in household food consumption patterns brought about by the economic crisis may increase malnutrition levels. For children in poor households, reducing consumption from already low levels, even for a short period, can have important and sometimes permanent cognitive, motor, social-emotional, educational and economic repercussions across the life-course (Walker et al., 2005; Fung and Ha, 2008).

Government health expenditures are likely to decline in real per capita terms. Even where health is prioritised within the overall budget, real health spending per capita may still fall. The quality of health care will likely diminish. Patients will be likely to defer care completely or only attend a doctor or hospital when the situation becomes critical, exacerbating child and maternal mortality. The global crisis may adversely affect HIV and AIDS prevention programmes in the Pacific, with the most adverse effect being on prevention efforts among high-risk groups - most at risk and especially vulnerable adolescents, sex workers, military personnel, maritime workers and men who have sex with men (World Bank, 2009).

The moderate gains in education made by Pacific Island countries are now under threat. More Pacific Island children may not enrol, drop out of school or may experience declines in the quality of education. If education budgets decline, teacher salaries may be delayed and public money for new school buildings, school repairs and school inputs such as teaching supplies may be greatly reduced. Large youth populations combined with school drop-outs already make youth employment a major concern for this sub-region, with the crisis only set to increase levels of youth unemployment. There are also sinister long-term impacts of deteriorating education outcomes affecting future economic growth (World Bank, 2008).

Abuse and exploitation of and violence against women and children, while difficult to measure, rise under conditions of economic stress (Harper et al., 2009). Recent research across a range of Pacific Island countries suggests that various forms of child abuse, violence and exploitation exist alongside significant levels of sexual violence against children (UNICEF, UNESCAP, ECPAT International and RRRT, 2008). There is a real danger that hidden impacts of the crisis such as hazardous work and increases in violence may not be addressed owing to their invisibility.

In short, unless the global economic crisis is responded to effectively, Pacific Island countries on track to meet MDGs could fall behind, while those that were already struggling to advance could be left even worse off. Governments in the Pacific must take all necessary measures to protect social sector budgets, especially to maintain and, if warranted, expand essential social services for children and women (health, education, HIV prevention, and protection from abuse, violence and exploitation). Donors should maintain their aid commitments to the Pacific during the economic crisis and must ensure that investments benefit those most in need. A 
new set of policy options, including formal social protection (safety net) mechanisms such as conditional cash transfers to the most vulnerable, and workfare programmes - targeting youth and women in particular - should be considered in the response to the current crisis, to aid recovery of any lost economic and social development and to lessen the impact of future crises (Ravallion, 2008).

1 The findings, interpretations and conclusions expressed in this paper are those of the author and do not necessarily reflect the policies or views of UNICEF. The designations do not imply an opinion on legal status of any country or territory, or of its authorities, or the delimitation of frontiers.

2 This paper focuses on 14 Pacific Island countries: Cook Islands, Federated States of Micronesia, Fiji Islands, Kiribati, Nauru, Niue, Palau, Republic of Marshall Islands, Samoa, Solomon Islands, Tokelau, Tonga, Tuvalu and Vanuatu.

3 Latest available data suggest Pacific Island women share only $37.4 \%$ of wage employment in the non-agricultural sector, a regional figure which has changed little from the $1990 \mathrm{MDG}$ baseline of 31.1\% (ADB, 2008; Prasad, 2009).

4 UNICEF Pacific 2009 estimate, excluding Timor-Leste, Papua New Guinea and the Pacific Island Territories.

5 The under-five mortality rate refers to the probability (expressed as a rate per 1,000 live births) of a child born in a specified year dying before reaching the age of five if subject to current age-specific mortality rates. The infant mortality rate is the probability (expressed as a rate per 1,000 live births) of a child born in a specified year dying before reaching the age of one if subject to current age-specific mortality rates.

6 The maternal mortality ratio refers to the annual number of deaths of women from pregnancyrelated causes per 100,000 live births.

7 Contraceptive prevalence rate refers to the percentage of women in union aged 15-49 currently using contraception.

8 Adolescent birth rate refers to the annual number of births to women aged 15-19 per 1,000 women in that age group. It is also referred to as the age-specific fertility rate for women aged 15-19.

9 Antenatal care (ANC) coverage refers to the percentage of women aged 15-49 who are attended at least once during pregnancy by a skilled health practitioner and the percentage attended by any provider at least four times. The only official data available in the Pacific slands appear to be for Vanuatu and Republic of Marshall Islands. One or more ANC visit during pregnancy is almost universal in Vanuatu; $84 \%$ of pregnant women received ANC from a skilled provider (i.e. doctor, nurse or midwife) at least once during their last pregnancy. An additional $14 \%$ received ANC from an unskilled provider. Only $2 \%$ of pregnant women did not receive any ANC (Government of Vanuatu, 2008). In the Marshall Islands $77 \%$ of women attended four or more visits for ANC (EPPSO, SPC and Macro International Inc., 2007). Unmet need for family planning refers to women who are fecund and sexually active but are not using any method of contraception and report not wanting any more children or wanting to delay the birth of the next child.

10 Comprehensive knowledge about HIV and AIDS transmission is defined as: (1) knowing methods of preventing HIV; (2) rejecting two common misconceptions regarding HIV; and (3) knowing that a healthy-looking person can have HIV.

\section{References}

Abbott, D. (2008) A Macroeconomic

Assessment of Poverty and Hardship in the Pacific: lessons, challenges and policy responses for achieving the MDGs, Suva: UNDP Pacific Centre

ADB (2008) Key Indicators for Asia and the Pacific, 39th edition, Manila: Asian Development Bank, available at: http:// www.adb.org/Documents/Books/Key_ Indicators/2008/pdf/Key-Indicators-2008. pdf

ADB (2009) Taking the Helm: a policy brief on a response to the global economic crisis, Manila: Asian Development Bank

EPPSO, SPC and Macro International Inc. (2007) Republic of the Marshall Islands Demographic and Health Survey 2007, Secretariat of the Pacific Community

Fung, W. and W. Ha (2008) Intergenerational Effects of the 1959-61 China Famine, New York: UNDP

Gottschalk, R. (2004) How Financial Crises Affect the Poor, London: DFID

Government of Palau (2008a) Situation Analysis of Children, Youth and Women

Government of Palau (2008b) The Millennium Development Goals: initial status report

Government of Vanuata and UNICEF (2008) Vanuatu Multiple Indicator Cluster Survey 2007: final report, Port Vila: National Statistics Office

Haberkorn, G. (2009) ëMonitoring MDG progress in Pacific Island countries: data availability, quality and accessí, paper presented at the UNESCAP-ADB-UNDP Pacific MDG workshop, Nadi, Fiji Islands, 16-20 March

Harper, C., N. Jones, A. McKay and J. Espey (2009) Children in Times of Economic Crisis: past lessons, future policies,
Overseas Development Institute

background paper, London: ODI

ILO (2009) Pacific NewsTok, newsletter of the ILO Office for Pacific Island Countries, International Labor Organization, available at http://www.ilo.org/wcmsp5/groups/ public/-asia/-ro-bangkok/documents/ publication/wcms_105182.pdf

IMF (2009) Global Economic Crisis: economic crisis starts to hit worldís poorest countries, International Monetary Fund, www.imf.org/external/pubs/ft/survey/ so/2009/NEW030309A.htm, accessed 16 June 2009

Prasad, B.C. (2009) ëMDGs in the Pacific Islands countries: taking stock, emerging issues and way forwardí, paper presented at the UNESCAP-ADB-UNDP Pacific MDG workshop, Nadi, Fiji Islands, 16-20 March

Ravallion, M. (2008) Bailing out the World's Poorest, policy research working paper 4763, Washington, D.C.: World Bank

SPC (2004) Regional MDG Report, Noumea: Secretariat of the Pacific Community, available at: http://www.spc.int/mdgs/

UNESCAP, ADB and UNDP (2008) A Future Within Reach: regional partnerships for the Millennium Development Goals in Asia and the Pacific, Bangkok: UNESCAP, available at http://www.unescap.org/pdd/ publications/MDGIII/MDGReport2008.pdf

UNICEF (2007) State of Pacific Children, Suva: UNICEF Pacific

UNICEF (2008) Progress for Children: a report card on maternal mortality, 7, September, New York: UNICEF, available at http://www. childinfo.org/files/progress_for_children_ maternalmortality.pdf

UNICEF (2009a) State of the World's Children, New York: UNICEF, available at http://www. unicef.org/sowc09/report/report.php
UNICEF (2009b) http://www.childinfo.org/ mortality.html, accessed 29 June 2009

UNICEF, UNESCAP, ECPAT International and RRRT (2008) Commercial Sexual Exploitation of Children and Child Sexual Abuse in the Pacific: a regional report, available at http://www.unicef.org/eapro/ Pacific_CSEC_report.pdf

United Nations (2000) Resolution adopted by the General Assembly. A/RES/55/2, available at http://www.un.org/ millennium/declaration/ares552e.pdf

Walker, S.P., S.M. Chang, C.A. Powell and S.M. Grantham-McGregor (2005) Effects of Early Childhood Psychosocial Stimulation and Nutritional Supplementation on Cognition and Education in Growth-Stunted Jamaican Children: prospective cohort study, Lancet, 366, pp.1804-7

World Bank (2008) Aggregate Economic Shocks, Child Schooling and Child Health, policy research working paper 4701 , available at http://www-wds.worldbank. org/external/default/WDSContentServer/ IW3P/IB/2008/08/25/000158349_200 80825161803/Rendered/PDF/WPS4701. pdf

World Bank (2009) Averting a Human Crisis During the Global Downturn: policy options from the World Bank's Human Development Network, available at http:// siteresources.worldbank.org/NEWS/ Resources/AvertingTheHumanCrisis.pdf WHO, SPC, UNSW and Global Fund (2006) Second Generation Surveillance Surveys of HIV, STIs and Risk Behaviours in Six Pacific Island Countries (2004-2005), available at http://www.spc.int/hiv/ HIV\%20SGS\%20Report\%20(Fiji,Kiribati, Samoa,Solomon\%20ls,Tonga,Vanuatu) (June\%202006).pdf 